\title{
Perceived Usefulness of "Flipped Learning" on Instructional Design for Elementary and Secondary Education: With Focus on Pre-service Teacher Education
}

\author{
Hiroki Yoshida
}

\begin{abstract}
Flipped learning" is implemented in elementary, secondary, and higher education levels. In the "flipped learning" process, pre-recorded video lectures are used to promote the productivity and effectiveness of face-to-face classroom activities. In such learning environments, it is expected that learners might consider not only the learning system or technology but also the learning process useful. However, previous studies have only focused on the perceived usefulness of a learning system or technology of "flipped learning" and few studies have focused on the usefulness of the learning process of "flipped learning." Therefore, this study purposed to identify the contents and structure of learners' perceived usefulness of "flipped learning." As a result, 14 usefulness statements were identified as items for anxiety in perceived usefulness of "flipped learning" on instructional design, and the 14 items were classified into four clusters: "enhancement of classroom instruction," "review and confirmation," "learning effectiveness," and "productivity and self-paced learning."
\end{abstract}

Index Terms-Flipped learning, instructional design, pre-service teacher education, Elementary education, secondary education.

\section{INTRODUCTION}

The term "flipped classroom" was first announced by two chemistry teachers Bergman and Sams in Woodland Park High School in Colorado in 2006 [1]. They used screen casting and video distributing technique to deliver their students introductory lessons and have students study at home. Thus, Bergman and Sams enabled students to use more class time for constructive activities. In recent years, the "flipped classroom" concept has been given a more educationcentered title "flipped learning," where emphasis is put on the learning process that students go though in order to master learning contents [2].

\section{A. Requirements and Advantages of "Flipped Learning"}

Currently, "flipped learning" is implemented in the elementary, secondary and higher education levels [3]. "Flipped learning" is defined by Bergmann and Sams [4] as "that which is traditionally done in class is now done at home, and that which is traditionally done as homework is now completed in class." With the utilization of "flipped learning," class becomes a place to work through problems, advance concepts, and engage in collaborative learning. Teachers and students can maximize one of the most significant learning

Manuscript received November 29, 2014; revised January 12, 2015.

Hiroki Yoshida is with Tokoha University, Shizuoka, Japan (e-mail: h-yoshida@av-lab.org). resource-time [5]. In essence, "flipped learning" is considered "a blending of direct instruction with constructivist learning [6]."

According to Bergman et al., "flipped learning" requires 1) the increase of interaction and personalized contact time between students and teachers, 2) an environment where students take responsibility for their own learning, 3) a classroom where the teacher is not the "guide on the side," 4) a class where content is permanently archived for review or remediation, 5) a class where all students are engaged in their learning, and 6) place where all students can get a personalized education [7]. Based on the definition and requirements of "flipped learning," Stone [8] identified three advantages of implementing "flipped learning" in higher education: 1) development of life-long learners, 2) increased engagement in the material, and 3) increased interactions between students and faculty.

\section{B. Perceived Usefulness of a New Technology}

In order to investigate users' acceptance behavior on new technology, many models were developed by researchers. Among them Technology Acceptance Model (hereinafter abbreviated as TAM) developed by Davis [9], [10] is one of the most extensively used research models to predict acceptance and use of new technology.

TAM theorizes that users' intention to adopt a new system or technology is determined by two beliefs: perceived usefulness and perceived ease of use. Perceived usefulness is defined as "the degree to which an individual believes that using a particular system would enhance his or her productivity" while perceived ease of use is defined as "the degree an individual believes that using a particular system would be free of effort [9], [10]." Davis [9] reported that users' belief about the usefulness of a new technology affects attitudes towards use, intention to use a new system, and is one of the strongest determinants of actual system usage. Saga and Zmud [11] advanced Davis's research and found that a user may adopt a new technology if he or she perceives it is convenient, useful, and socially desirable even though they do not enjoy using it.

Davis [9] developed and validated measurement scales for perceived usefulness and perceived ease of use. Both of the scales consisted of 6 items that measure users' belief on new technology on a ten-point Likert scale. In the study, Davis [9] identified three main clusters of perceived usefulness: job effectiveness, productivity and time savings, and importance of the system to ones' job, and three main clusters of perceived ease of use: physical effort, mental effort, and perceptions of how easy a system is to learn. 
Recent studies on e-learning have reported learners' or users' perceived usefulness and perceived ease of use on online learning systems or environments. Masrom [12], Lee et al. [13], and Tagoe [14] developed scales based on the TAM that measure learners' beliefs on e-learning. However, they did not adopt all of the items introduced in the TAM. Abdel-Wahab [15] and Eke [16] adopted four items to measure learners' perceived usefulness and perceived ease of use of e-learning and introduced subscales that were not reported in the TAM. They introduced a new subscale "learners' satisfaction" for the perceived usefulness, and a subscale "interaction between learners and educator" for perceived ease of use. These studies suggest that leaners' belief in e-learning consists not only of usefulness and ease of use of the system but also the usefulness and ease of use of the learning process.

Different from computer assisted instruction (CAI) and Web-based training (WBT), "flipped learning" requires learners to collaborative in order to complete project-based activities, and video lectures are used to promote the productivity and effectiveness of face-to-face classroom activities. In such learning environments, it is expected that learners might consider not only the learning system or technology but also the learning process useful.

Given the situation, it is important to identify what learners believe useful and easy of "flipped learning." Although, we recognized the significance of perceived ease of use in "flipped learning", we decided to focus on learners' perceived usefulness in this study. This is because it was predicted that most of the students were to access the preparation videos via smartphones and they would find it easy to operate the videos as most of the students possessed a smartphone. Therefore, this study aims to identify the contents and structure of learners' perceived usefulness of "flipped learning."

\section{PURPOSE}

The purpose of this study is to identify perceived usefulness of "flipped learning" on instructional design for elementary and secondary education. The research questions to be addressed in this study are: 1) What do university students majoring in education find useful about "flipped learning?" 2) What is the structure of participants' perceived usefulness of "flipped learning?"

\section{METHOD}

A questionnaire survey was conducted on October 30th, 2012, with the purpose of identifying participants' perceived usefulness of "flipped learning"

\section{A. Participants}

Participants were 66 Japanese third-year university students who participated in an educational technology class. All of the participants were taking pre-service teacher education courses for elementary and secondary education. All of them had never experienced "flipped learning" before. Participants were experiencing "flipped learning" for five weeks at the time of the questionnaire survey.

\section{B. Questionnaire}

A self-report questionnaire sheet, which was a written form of free-response style, was used to identify learners' perceived usefulness of the "flipped learning." Participants were asked what they find useful about "flipped learning"

\section{Structure of the Lessons}

All of the participants attended a "flipped" educational technology class. They studied how to design, manage, and evaluate elementary and secondary classroom lessons. Participant experienced "flipped learning" for five weeks before they responded to the questionnaire survey in order to identify their perceived usefulness of "flipped learning." Students studied via pre-recorded video lectures that were posted on the class website before class and they performed project-based activities related to instructional design in class. Each lesson was structured as follows:

(Pre-recorded video lectures: $40 \mathrm{~min}$.)

1) Mini-quizzes on the videos: $5 \mathrm{~min}$.

2) Q \& A time on the videos: $5 \mathrm{~min}$.

3) Mini-lecture: $15 \mathrm{~min}$.

4) Instruction on the activity: $5 \mathrm{~min}$.

5) Project-based activity: $60 \mathrm{~min}$.

Total: $90 \mathrm{~min}$.

\section{RESULTS}

Among the 66 participants, 64 completed a questionnaire survey that was conducted in an educational technology class. This means that the response rate was 96.97 percent. Hereinafter, the results of the 64 answers will be introduced and analyzed.

\section{A. Participants' Profile}

Table I shows the breakdown of participants by gender, major, and teacher education courses they enrolled. The reason for the large proportion of the females is that 93.4 percent of kindergarten teachers and 62.5 percent of elementary school teachers in Japan are females, and most of the participants enrolled in the elementary education pre-service teacher education course [17].

\section{B. Perceived Usefulness of "Flipped Learning"}

The KJ method was used to group participants' perceived usefulness of "flipped learning" In order to achieve validity and reliability of the classification and grouping of the anxiety, the procedure was helped by a researcher majoring in educational psychology and a researcher majoring in lifelong education. As a result, 20 usefulness statements were determined for perceived usefulness in "flipped learning" (see Table II).

Results of the survey reveal that one fourth of the participants found "flipped learning" useful because learners can study through the video over and over again, "flipped learning" enhances learners understanding, learners can study at their pace, learners can stop the video whenever they want to, learners can study though the video on their own time, and "flipped learning" enhances the effectiveness of classroom lessons.

Among the 20 perceived usefulness statements decided in 
this study, 9 statements are related with usefulness items described in the previous studies. Item \# 3 ("Flipped learning" is useful because learners can study at their own pace.), \# 4 ("Flipped learning" is useful because learners can stop the video whenever they want to.), \# 5 ("Flipped learning" is useful because learners can study on their own time.), \# 6 ("Flipped learning" is useful because it enhances the effectiveness of classroom lessons.), \# 10 ("Flipped learning" is useful because it provides prior knowledge for projectbased activities in classroom.), \# 11 ("Flipped learning" is useful because it enhances learners practical expertise.) are perceived usefulness items that are included in Davis's Perceived Usefulness Scale [9]. Item \# 2 ("Flipped learning" is useful because it enhances learners' understanding.), \# 15 (Flipped learning" is useful because learners can concentrate on their study.), and \# 18 (Flipped learning" is useful because it enhances learners' motivation.) are statements related with perceived usefulness items noted by Abdel-Wahab [15] and Eke [16]. The rest of the items cannot be found in previous perceived usefulness scales or items.

TABLE I: PROFILE OF PARTICIPANTS

\begin{tabular}{|c|c|c|c|}
\hline \multicolumn{2}{|c|}{ Profile of participants } & \multirow{2}{*}{$\begin{array}{r}\text { Frequency } \\
22\end{array}$} & \multirow{2}{*}{$\frac{\%}{34.38 \%}$} \\
\hline Gender & Male & & \\
\hline 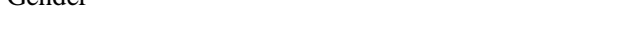 & Female & 42 & $65.62 \%$ \\
\hline & Total & 64 & $100.00 \%$ \\
\hline \multirow{7}{*}{ Major } & Lifelong learning & 6 & $9.38 \%$ \\
\hline & Physical education & 23 & $35.94 \%$ \\
\hline & Educational psychology & 21 & $32.81 \%$ \\
\hline & Educational counseling & 12 & $18.75 \%$ \\
\hline & English education & 1 & $1.56 \%$ \\
\hline & Art education & 1 & $1.56 \%$ \\
\hline & Total & 64 & $100.00 \%$ \\
\hline \multirow{9}{*}{ Teacher education courses enrolled (multiple answers) } & Kindergarten education & 5 & $7.81 \%$ \\
\hline & Elementary education & 54 & $84.38 \%$ \\
\hline & Secondary education (Japanese) & 6 & $9.38 \%$ \\
\hline & Secondary education (Social studies) & 2 & $3.13 \%$ \\
\hline & Secondary education (Physical education) & 21 & $32.81 \%$ \\
\hline & Secondary education (Music education) & 1 & $1.56 \%$ \\
\hline & Secondary education (English education) & 1 & $1.56 \%$ \\
\hline & Secondary education (Art education) & 1 & $1.56 \%$ \\
\hline & Special needs education & 18 & $28.13 \%$ \\
\hline
\end{tabular}

TABLE II: PERCEIVED USEFULNESS OF "FLIPPED LEARNING"

\begin{tabular}{|c|c|c|}
\hline Items & Frequency & $\%$ \\
\hline \multicolumn{3}{|l|}{ "Flipped learning" is useful because... } \\
\hline 1. learners can study through the video over and over again. & 42 & $65.63 \%$ \\
\hline 2. it enhances learners' understanding. & 34 & $53.13 \%$ \\
\hline 3. learners can study at their own pace. & 20 & $31.25 \%$ \\
\hline 4. learners can stop the video whenever they want to. & 19 & $29.69 \%$ \\
\hline 5. learners can study on their own time. & 19 & $29.69 \%$ \\
\hline 6. it enhances the effectiveness of classroom lessons. & 16 & $25.00 \%$ \\
\hline 7. it develops learners' readiness for classroom lessons. & 14 & $21.88 \%$ \\
\hline 8. it increases the amount of project-based activities in classroom. & 13 & $20.31 \%$ \\
\hline 9. learners can use the videos to review what they learned. & 13 & $20.31 \%$ \\
\hline 10. it provides prior knowledge for project- based activities in classroom. & 13 & $20.31 \%$ \\
\hline 11. it enhances learners practical expertise. & 12 & $18.75 \%$ \\
\hline 12. learners can check their understanding through quizzes on the videos. & 10 & $15.63 \%$ \\
\hline 13. learners can identify what are important through quizzes on the videos. & 8 & $12.50 \%$ \\
\hline 14. learners can develop study habits. & 7 & $10.94 \%$ \\
\hline 15. learners can concentrate on their study. & 2 & $3.13 \%$ \\
\hline 16. it is useful for designing classroom lessons. & 2 & $3.13 \%$ \\
\hline 17. learners can study on mobile-phones/smartphones. & 2 & $3.13 \%$ \\
\hline 18. it enhances learners' motivation. & 1 & $1.56 \%$ \\
\hline 19. learners can download the videos. & 1 & $1.56 \%$ \\
\hline 20. learners can study through their eyes and ears. & 1 & $1.56 \%$ \\
\hline
\end{tabular}




\section{Statistical Analysis}

Participants' responses were classified using Hayashi's quantification method type III. Item \# 15 ("Flipped learning" is useful because learners can concentrate on their study.), \#16 (Flipped learning" is useful because it is useful for designing classroom lessons.), \#17 (Flipped learning" is useful because learners can study on mobile-phones/ smartphones.), and \#18 (Flipped learning" is useful because it enhances learners' motivation.), \# 19 (Flipped learning" is useful because learners can download the videos.), \# 20 (Flipped learning" is useful because learners can study through their eyes and ears.) were deleted from further analysis because few participants commented that they found "flipped learning" useful for these reasons, and if the items were included in the statistical analysis, they put too much category weight to all of the axes. Thus, 14 usefulness items were selected to be analyzed.

Table III shows the normalized category weights given to participants' perceived usefulness of "flipped learning" According to the tendency of the decrease of the eigenvalue (first axis: 0.6914, second axis: 0.4557, third axis: 0.3399, fourth axis: 0.1961 ) and the cumulative proportion (first axis: 29.45 percent, second axis: 48.87 percent, third axis: 63.35 percent, forth axis: 71.70 percent), three axes were determined and interpreted.

TABLE III: NORMALIZED CATEGORY WEIGHTS TO PARTICIPANTS' PERCEIVED USEFULNESS OF "FLIPPED LEARNING"

\begin{tabular}{|c|c|c|c|}
\hline Category & Axis 1 & Axis 2 & Axis 3 \\
\hline \multicolumn{4}{|l|}{ "Flipped learning" is useful because... } \\
\hline 11. it enhances learners practical expertise. & 1.7015 & 0.3429 & -0.3451 \\
\hline $\begin{array}{l}\text { it provides prior knowledge for } \\
\text { project-based activities in classroom. }\end{array}$ & 1.6433 & 0.6683 & -0.3862 \\
\hline $\begin{array}{l}\text { it increases the amount of project based } \\
\text { activities in classroom. }\end{array}$ & 1.6271 & 0.3010 & -0.3796 \\
\hline $\begin{array}{l}\text { it enhances the effectiveness of } \\
\text { classroom lessons. }\end{array}$ & 1.4292 & 0.6982 & 0.0158 \\
\hline $\begin{array}{l}\text { it develops learners' readiness for } \\
\text { classroom lessons. }\end{array}$ & 1.0345 & 0.5126 & 0.2351 \\
\hline $\begin{array}{l}\text { learners can use the videos to review } \\
\text { what they learned. }\end{array}$ & -0.5446 & 0.4816 & 3.1783 \\
\hline $\begin{array}{l}\text { learners can study through the video } \\
\text { over and over again. }\end{array}$ & -0.7450 & 0.3391 & 0.6764 \\
\hline 2. it enhances learners' understanding. & -0.2817 & -0.3979 & 0.2671 \\
\hline $\begin{array}{l}\text { 12. learners can check their understanding } \\
\text { through quizzes on the videos. }\end{array}$ & 0.3917 & -3.1711 & 0.0724 \\
\hline $\begin{array}{l}\text { 13. learners can identify what are important } \\
\text { through quizzes on the videos. }\end{array}$ & 0.4297 & -3.5503 & 0.0522 \\
\hline $\begin{array}{l}\text { learners can study though the video on } \\
\text { their own time. }\end{array}$ & -0.8951 & 0.2612 & -0.8826 \\
\hline $\begin{array}{l}\text { learners can stop the video whenever } \\
\text { they want to. }\end{array}$ & -0.8767 & 0.3269 & -0.9259 \\
\hline 3. learners can study at their pace. & -0.9030 & 0.3289 & -1.0592 \\
\hline 14. learners can develop study habits. & -1.1375 & 0.0464 & -1.9790 \\
\hline
\end{tabular}

Results of the statistical analysis indicate that the participants' perceived usefulness of "flipped learning" can be classified into four clusters.

The first cluster consists of five items: item \# 11 ("Flipped learning" is useful because it enhances learners practical expertise.), \# 10 ("Flipped learning" is useful because it provides prior knowledge for project-based activities in classroom.), \# 8 ("Flipped learning" is useful because it increases the amount of project based activities in classroom.), \# 6 ("Flipped learning" is useful because it enhances the effectiveness of classroom lessons.), and \# 7 ("Flipped learning" is useful because it develops learners' readiness for classroom lessons.), that had high category scores on the first correlation axis, comparatively high scores on the second axis, and comparatively low scores on the third axis. As all of the five items are related with perceived usefulness of "flipped learning" on classroom lessons, the first cluster was given the name "enhancement of classroom instruction."

The second cluster includes two items: \# 9 ("Flipped learning" is useful because learners can use the videos to review what they learned.) and \# 1 ("Flipped learning" is useful because learners can study through the video over and over again.), that had high category scores on the third correlation axis and relatively low scores on the first and second axis. Both of the items are related with perceived usefulness of "flipped learning" on reviewing and confirming the learning contents. Therefore, the second cluster was named "review and confirmation."

The third cluster also consists of three items: \# 2 ("Flipped learning" is useful because it enhances learners' understanding.), \# 12 ("Flipped learning" is useful because learners can check their understanding through quizzes on the videos.), and \# 13 "Flipped learning" is useful because learners can identify what are important through quizzes on the videos.), that had highly negative scores on the second correlation axis and relatively low category scores on the first and third axis. All of the three items are related with perceived usefulness of "flipped learning" on learners' understandings of the learning contents, and therefore was given the name "learning effectiveness."

The fourth cluster consists of four items: \# 5 ("Flipped learning" is useful because learners can study though the video on their own time.), \# 4 ("Flipped learning" is useful because learners can stop the video whenever they want to.), \# 3 ("Flipped learning" is useful because learners can study at their pace.), and \# 14 ("Flipped learning" is useful because learners can develop study habits.), that had highly negative scores on the first and third axis, and relatively low scores on the second axis. As all of the four items are related with perceived usefulness of "flipped learning" on learning efficiently at learners' pace and time, the fourth cluster was given the label "productivity and self-paced learning."

\section{DISCUSSIONS}

The purpose of the study was to identify Japanese university students' perceived usefulness of "flipped learning" on instructional design for elementary and secondary education. In order to gather learners' perceived usefulness statements on "flipped learning," an open-ended question was used.

1) What do university students majoring in education find 
useful about "flipped learning?" 2) What is the structure of participants' perceived usefulness of "flipped learning."

Regarding the first research question "What do university students majoring in education find useful about "flipped learning?"' results of the questionnaire survey show that university students who are enrolled in elementary and secondary education courses found flipped learning" useful because they can study through the video over and over again, "flipped learning" enhances their understanding, they can study at their pace, they can stop the video whenever they want to, they can study though the video on their own time, and "flipped learning" enhances the effectiveness of classroom lessons.

With regard to the second research question "What is the structure of participants' perceived usefulness of 'flipped learning?," statistical analysis using Hayashi's quantification method type III revealed that participants' perceived usefulness can be describe by three axes, and the usefulness of "flipped learning" can be classified into four groups, namely, "enhancement of classroom instruction," "review and confirmation," "learning effectiveness," and "productivity and self-paced learning."

\section{CONCLUSION}

The results of the study suggest that learners' perceived usefulness of "flipped learning" on instructional design consists of not only technology-related usefulness but also usefulness of the learning process. As "flipped learning" is not a synonym of online videos of online courses [7], but is an "a blending of direct instruction with constructivist learning [5]," it is significant to focus on the whole learning process to ensure the quality of "flipped learning."

Since the participants of the present study are Japanese university students who major in education, using other samples from elsewhere is expected for future generalization of the items.

Given the findings of this study, it is necessary to develop a perceived usefulness scale on "flipped learning" and examine the validity and reliability of the scale. By doing so, it would be possible to identify what kind of learners find what kind of aspects of "flipped learning" useful, leading to what kind of learning attitude, behavior and achievements. Moreover, future studies should investigate the relationship of leaners' perceived usefulness, perceived ease of use, and acceptance of "flipped learning" according to the TAM.

The findings of this study should contribute to suggest instructors how to promote learners' perceived usefulness on "flipped learning." "Flipped learning" requires learners to autonomously study at home and collaboratively study in class. In such a learning environment, learners might need tutoring or mentoring that helps their individual learning at home, and facilitation or guidance that enhances cooperative communication and collaborative activities in class. It is anticipated to identify the roles of teachers in "flipped" classes with the purpose of helping learners learn effectively at home and work productively in class.

\section{REFERENCES}

[1] T. Long, C. Su, and M. Waugh/ (November 2014). Using a flipped-classroom instructional model in a large-enrollment undegraduate genetics class: An action research study. [Online]. Available: http://www.aect.org/pdf/proceedings13/2013/13_17.pdf

[2] C. L. Thoms, "Maximizing the blended learning curriculum by using the 'flipped classroom' approach in the workplace," presented at the International Conference on e-Learning in the Workplace, New York, NY, June 12-14, 2013.

[3] J. Bormann. (May 2014). Affordances of Flipped Learning and its Effects on Student Engagement and Achievement. [Online]. Available: http://flippedlearning.org/cms/lib07/VA01923112/Centricity/Domain /41/bormann_lit_review.pdf

[4] J. Bergmann and A. Sams, Flip you Classroom: Reach Every Student in Every Class Every Day, International Society for Technology in Education, 2012.

[5] B. Tucker, "The flipped classroom: Online instruction at home frees class time for learning," Education Next, Winter 2012, pp. 82-83, 2012.

[6] B. Baker, B. S. Kuts, and L. Wilkinson, "Double live gonzo! double your Impact with a flipped classroom," LOEX Quarterly, vol. 39, pp. 12-15, 2013

[7] J. Bergmann, J. Overmyer, and B. Willie. The flipped class: Myths vs Reality. [Online]. Available: http://www.thedailyriff.com/articles/the-flipped-class-conversation-6 89.php

[8] B. B. Stone. Flip your classroom to increase active learning and student engagement. presented at the 28th Annual Conference on Distance Teaching \& Learning. [Online]. Available: http://www.uwex.edu/disted/conference/Resource_library/proceeding s/56511_2012.pdf

[9] F. D. Davis, "Perceived usefulness, perceived ease of use, and user acceptance of information technology," MIS Quarterly, September 1989, pp. 319-340.

[10] F. D. Davis, R. P. Bagozzi, and P. R. Warshaw, "User acceptance of computer technology: A comparison of two theoretical models," Management Science, vol. 35, no. 8, pp. 982-1003, 1989

[11] V. K. Saga and R. W. Zmud, "The nature and determinants of IT acceptance, routinization and infusion," in Proc. the IFIP TC8 Working Conference on Diffusion, Transfer and Implementation of Information Technology, North Holland, 1994.

[12] M. Masrom, "Technology acceptance model and e-learning," presented at the 12th International Conference on Education, pp. 1-6, May 21-24, 2007.

[13] B.-C. Lee, J.-O. Yoon, and I. Lee, "Learners' acceptance of e-learning in South Korea: Theories and results," Computers \& Education, vol. 53, pp. 1320-1329, 2009.

[14] M. Tagoe, "Students' perceptions on incorporating e-learning into teaching and learning at the University of Ghana," International Journal of Education and Development Using Information and Communication Technology, vol. 8, no. 1, pp. 91-103, 2012.

[15] A. G. Abdel-Wahab, "Modeling students' intention to adopt E-learning: A case from Egypt," The Electronic Journal of Information Systems in Developing Countries, vol. 34, no. 1, pp. 1-13, 2008.

[16] H. N. Eke. (November 2014). Modeling LIS Students' Intention to Adopt E-learning: A Case from University of Nigeria. Nsukka. Library Philosophy and Practice. [Online]. Available: http://digitalcommons.unl.edu/cgi/viewcontent.cgi?article=1496\&con text=libphilprac

[17] FY 2013 School Basic Survey, Ministry of Education, Tokyo, 2013.

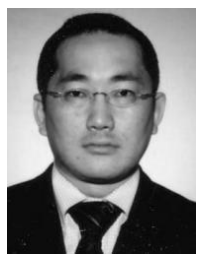

H. Yoshida was born in Nara, Japan in 1973. He received the MEd in educational technology from International Christian University, Japan in 2001. He is currently a professor at Tokoha University in Shizuoka Japan. His research interests include teacher education, online learning, cooperative learning, and hypermedia education. 